\title{
Hemangiolymphangioma with Accompanying Interstitial Lung Disease: A Rare Case
}

\author{
Interstistiyel Akciğer Hastalığı ile Seyreden Hemanjiyolenfanjioma: \\ Nadir Bir Olgu
}

Gülçehre Oğuztürk', Selin Onay Mahmuti², Ece Yasemin Demirkol², Neslihan Fener ${ }^{3}$, Ekrem Cengiz Seyhan', Erdoğan Çetınkaya', Muzaffer Metin²

\begin{abstract}
Vascular anomalies are pathologies that occur in embryonic life that affect the lymphatic and capillary systems, and can be classified as vascular tumors or vascular malformations, according to their histological features. They are rare and are mostly detected in the first years of life. Hemangiolymphangiomas are benign vascular tumors containing lymphatic and capillary-system elements with a reported incidence of 1: 12,000 in newborns. The cases reported to date have been in the head (oral cavity, orbita, etc.), neck and mediastinum regions. We presented here a case of a 17-year-old male patient who was diagnosed with hemangiolymphangioma after a videoassisted lung biopsy (VATS) with accompanying interstitial lung disease. The patient, who had no history of chronic disease, presented to the outpatient clinic complaining of cough and shortness of breath for eight months. Interstitial lung features were observed in the patient's thorax computer tomography. After the VATS procedure, the patient developed chylothorax, and the pathology results indicated hemangiolymphangioma.
\end{abstract}

Key words: Hemangiolymphangioma, chylothorax, interstitial, lung.

\section{Özet}

Vasküler anomaliler, embriyonik yaşamda oluşan, lenfatik ve kapiller sistemleri etkileyen patolojilerdir ve histolojik özelliklerine göre vasküler tümörler veya vasküler malformasyonlar olarak sınıflandırılırlar. Nadir görülürler ve daha çok yaşamın ilk yıllarında saptanırlar. Hemaniiyolenfanjiyomlar da lenfatik ve kapiller sistem elemanları içeren, benign bir vasküler tümördür. İnsidansı yenidoğanlarda 1/12.000 olarak bildirilmiştir. Bugüne dek bildirilen olgular baş bölgesi (ağız boşluğu, orbita vs), boyun ve mediasten bölgelerindedir. Biz de bu makalede interstistiyel akciğer hastalığı ile seyreden ve yapılan tanısal video yardımlı akciğer biyopsisi (VATS) işlemi sonrasında hemanjiyolenfanjiyoma tanısı alan 17 yaşında bir erkek hastayı sunduk. Kronik bir hastalığı olmayan ve sekiz aydır olan öksürük ve nefes darlığı ile polikliniğe başvuran hastaya çekilen toraks tomografisinde interstistiyel akciğer özellikleri görülmüş olup; VATS işlemi sonrasında hastada şilotoraks gelişti. Patoloji sonucu hemanjiyolenfanjiyom olarak sonuçlandı.

Anahtar Sözcükler: Hemaniiyolenfaniiyom, şilotoraks, interstistiyel, akciğer.

'Department of Chest Diseases, Health Science University, Yedikule Training and Research Hospital for Chest Diseases and Thoracic Surgery, İstanbul, Turkey

${ }^{2}$ Department of Thoracic Surgery, Health Science University, Yedikule Training and Research Hospital for Chest Diseases and Thoracic Surgery, İstanbul, Turkey

${ }^{3}$ Department of Pathology, Health Science University, Yedikule Training and Research Hospital for Chest Diseases and Thoracic Surgery, ìstanbul, Turkey

Submitted (Başvuru tarihi): 06.02.2021 Accepted (Kabul tarihi): 24.05.2021

Correspondence (iletişim): Gülçehre Oğuztürk, Department of Chest Diseases, Health Science University, Yedikule Training and Research Hospital for Chest Diseases and Thoracic Surgery, i̇stanbul, Turkey

e-mail:gulcehre13@hotmail.com

*This case report was accepted and presented as an Poster presentation at UASK Congress on March 11-15, 2020.

'SBÜ Yedikule Göğüs Hastalıkları ve Göğüs Cerrahisi Eğitim ve Araştırma Hastanesi, Göğüs Hastalıkları Kliniği, İstanbul ${ }^{2}$ SBÜ Yedikule Göğüs Hastalıkları ve Göğüs Cerrahisi Eğitim ve Araşıırma Hastanesi, Göğüs Cerrahisi Kliniği, İstanbul

${ }^{3}$ SBÜ Yedikule Göğüs Hastalıkları ve Göğüs Cerrahisi Eğitim ve Araştırma Hastanesi, Patoloji Kliniği, İstanbul 
Vascular malformations occur as a result of anomalies in the capillary, lymphatic and venous systems during embryonic life and are classified as capillary, venous, lymphatic, arterial, mixed according to their content (1).

Hemangiolymphangiomas are defined as rare vascular malformations that contain endothelial-lymphatic components. Its incidence is 1: 12,000 and they are discovered at a rate of $40-60 \%$ at birth and $80-90 \%$ in the first 2 years of life. In the cases reported so far, the anterior and posterior cervical triangles are the most common areas in the body where hemangiolymphangiomas are seen, as well as duodenum, mediastinum, mouth, maxillofacial region, colon, bladder, testis and vertebra involvement (2).

Although clinical diagnosis can be made by physical examination, methods such as doppler ultrasonography, computed tomography (CT) and magnetic resonance (MRI) are useful (3).

Although being generally nonspecific at diagnosis; chest radiographs may show diffuse interstitial pattern and sometimes pleural effusion. Septal wall thickening due to peri-bronchial edema can be seen on thorax CT. Even if there are a few cases diagnosed after transbronchial biopsy, lung biopsy is considered to be the most accurate diagnostic method. (3)

Since hemangiolymphangiomas are considered benign, there is usually not much information about their prognosis, although first-line surgery is recommended as a treatment, agents such as bevacizumab and beta blockers have become prominent in recent years due to their low toxicity (4).

In most cases; hemangiolymphangiomas preset at infancy. What made our case remarkable was that our patient was a 17 years old male with a complaint of cough only for one month. We presented our case in the light of the literature.

\section{CASE}

A 17-years old male patient who hadn't had a known chronic disease admitted to our chest diseases outpatient clinic with the complaint of cough and shortness of breath for about 8 months. He had a height of $183 \mathrm{~cm}$ with a weight of $65 \mathrm{~kg}$ and had a history of neither smoking nor abusing alcohol and drugs.

In the interrogation it was learned that the patient applied to another hospital before 8 months with an ongoing cough for one month; a thorax CT was performed and interstitial lung disease (ILD) was considered as prediagnosis. A bronchoalveolar lavage (BAL) was performed through bronchoscopy and eosinophil ratio was $\% 5$ in BAL along with eosinophilia. A lung biopsy was recommended but the patient didn't have it performed then. The patient decided to apply to our hospital 8 months later than his first visit to hospital upon getting his cough getting severe.

The patient was questioned for additional complaints, he did not describe sputum, hemoptysis, chest pain, or a recent travel history. In the physical examination, there was no pathological feature other than the fine rales heard in the lower zones, and his vital signs were normal. A posteroanterior chest radiograph was requested.

On the radiograph, bronchiectasis areas on bilateral lower lung zones and peri-bronchial edema originating from interstitial tissues of the bronchial wall were observed (Figure 1).

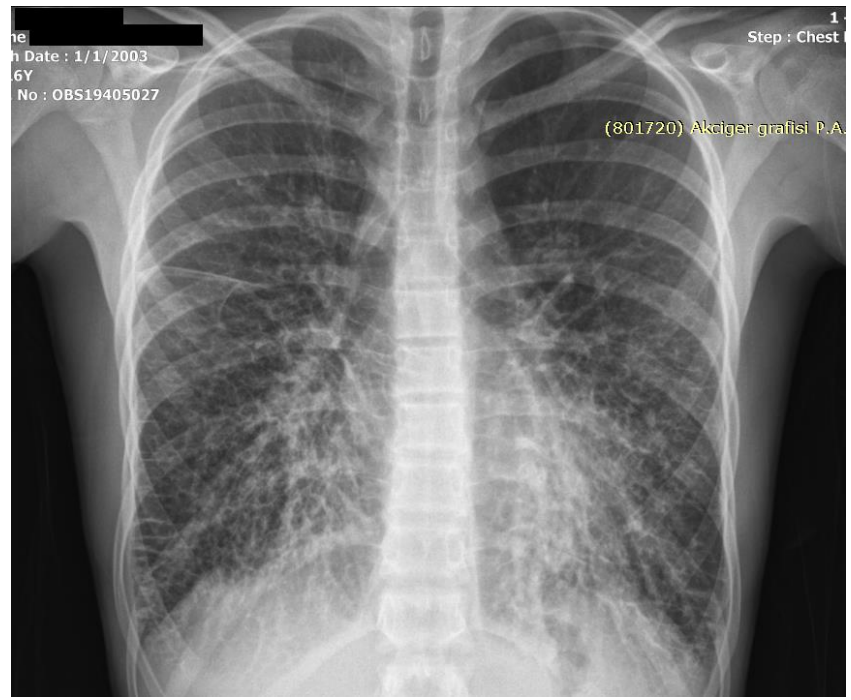

Figure 1: Preoperative chest radiography of the patient; bilateral bronchiectasis and the honey-comb view

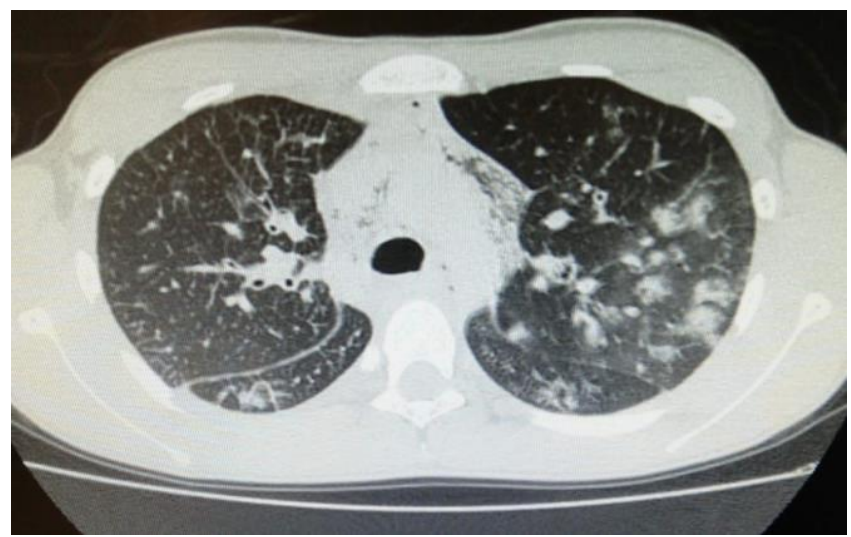

Figure 2: Thorax Tomography of the patient taken in an external hospital before the operation; Increases in thickness in the interlobular septum, ground glass on the right periphery 
The patient's external center CT was examined; increased interlobular septal thickness in both lungs and peribronchial consolidations (Figure 2), a budding tree appearance and pneumomediastinum, were (sarcoidosis or eosinophilic lung disease) seen more prominently in the upper lobe of the left lung (Figure 3). We decided to present the patient in the surgical council for the diagnostic procedure and ILD was our prediagnosis. The respiratory function test (PFT) performed before the operation showed a restrictive pattern. FVC was $3.12 \mathrm{~L}$ (59\%), FEV1 3.04 L (70\%), FEV1 / FVC: 97\%. After the surgical council, it was decided to perform a diagnostic video-assisted lung biopsy (VATS).

A wedge resection for lower and middle lobe of the right lung was performed. With double-lumen intubation under general anesthesia, ports were placed in the left lateral decubitus position, through the right 7 th intercostals space midaxillary line and 5th anterior axillary line incision, and an endocamera was inserted into the thorax wall to do a thoracoport incision. Wedge resection was performed from the right lower and middle lobes with the help of 1 endolineer stapler. Pleural effusion material was sampled for investigation. After hemostasis and aerostasis, a 28-fr drain was placed and the layers were duly closed, and the obtained biopsy material was sent to pathology. The patient's general condition and vitals remained stable after the procedure.

The day after the VATS procedure, pleural fluid sample was sent to the laboratory upon seeing chylous white liquid was seen in the chest drain tube of the patient and the results were supporting chylothorax. (Biochemical results of the fluid sample were glucose $37 \mathrm{mg} / \mathrm{dl}$; protein $38 \mathrm{mg} / \mathrm{dl}$; albumin $23 \mathrm{mg} / \mathrm{dl}$; LDH $675 \mathrm{mg} / \mathrm{dl}$, triglyceride $120 \mathrm{mg} / \mathrm{dl}$ and ph: 7.5) Since the chylothorax hadn't regressed lymphatic ligation was applied to the patient. One week after the ligation, upon being stable; the patient was discharged from the thoracic surgery ward.

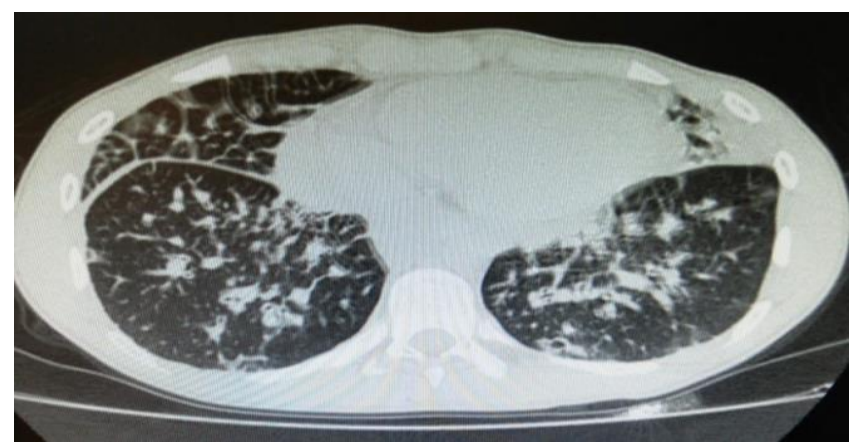

Figure 3: Tree in bud view, peripheral consolidations and pneumomediastinum prominent in left upper zone

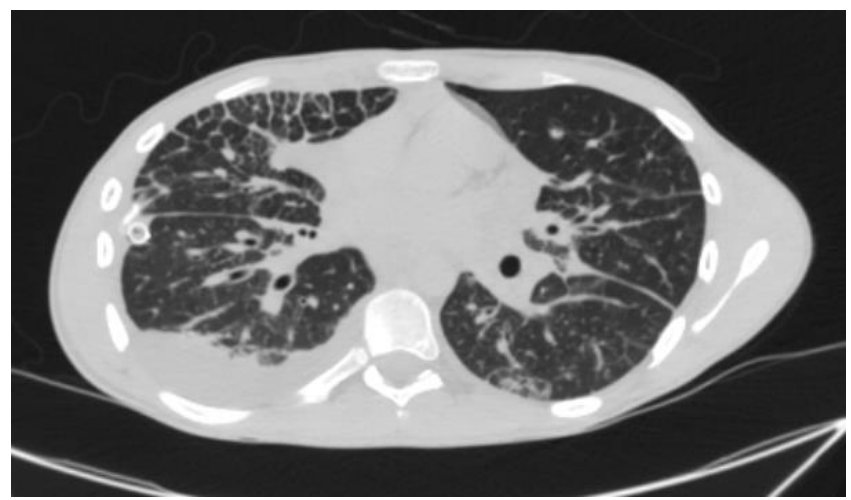

Figure 4: Thoracic CT taken after the operation; bilateral pleural effusion, more prominent on the right, increased fibroreticular density accompanied by traction bronchiectasis, irregular and coarse plaural fibrotic shrinkage, and $17.5 \mathrm{~mm}$ diameter nodular infiltrates, the largest in the left lower lobe laterobasal segment in both lungs

The histopathological examination of the biopsy material was resulted as "proliferating dilated vascular structures, hemangiomatosis and lymphangiomatosis spreading along the pleura and interlobar septa". Proliferation and dilatation of lymphatic and blood vessels were existing in the subpleural area. Staining results from the pathology laboratory were CD-31, D2-40 and CD-34 positive (Figure 5).

The patient was followed up with Propranolol oral therapy of $3 \times 20 \mathrm{mg}$. PFT values at the outpatient clinic control 2 months after the operation were; FVC $3.13 \mathrm{~L}$ (61\%), FEV1 $3.08 \mathrm{~L}$ (72\%), FEV1 / FVC: 102\%, DLCO 8.93 $\mathrm{ml} / \mathrm{min} / \mathrm{mmHg}$ (86\%), besides the patient had no active complaints. Not a significant change was observed at his chest x-ray though (Figure 6).

The patient's next visit to hospital was 18 months after his operation. It is learned that he had continued taking propranolol on same dose for 18 months and had no additional complaint. His physical examination as well as his vital signs were normal. A thorax CT was taken for control; in both lungs, there were polygonal views and septal nodules formed by prominent interlobular septal regular thickening in the middle lower lobe, as well as increased peribronchial nodular opacity in the subpleural area on the left in the basal and faintly circumscribed ground glass infiltrates in the upper lobes. Pleural effusion extending into the fissure at a depth of $4 \mathrm{~cm}$ on the right lung was observed (Figure 7). It was decided to continue the same treatment while chest surgery outpatient clinic control was recommended for his recently developed pleural effusion. 


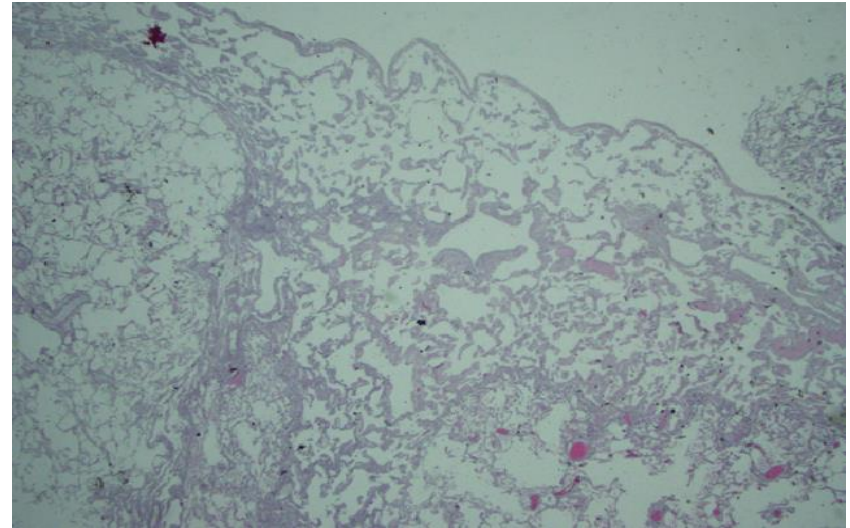

Figure 5: 2x10 HE pleural face dilated lymphovascular vessel proliferation-pathology preparation

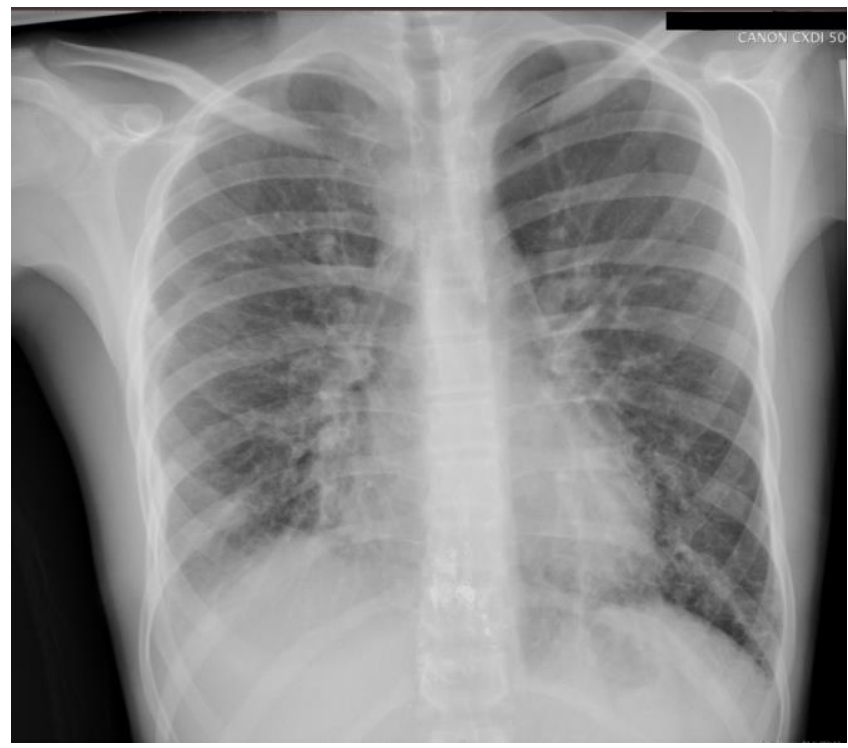

Figure 6: Chest $x$-ray taken 2 months after the operation

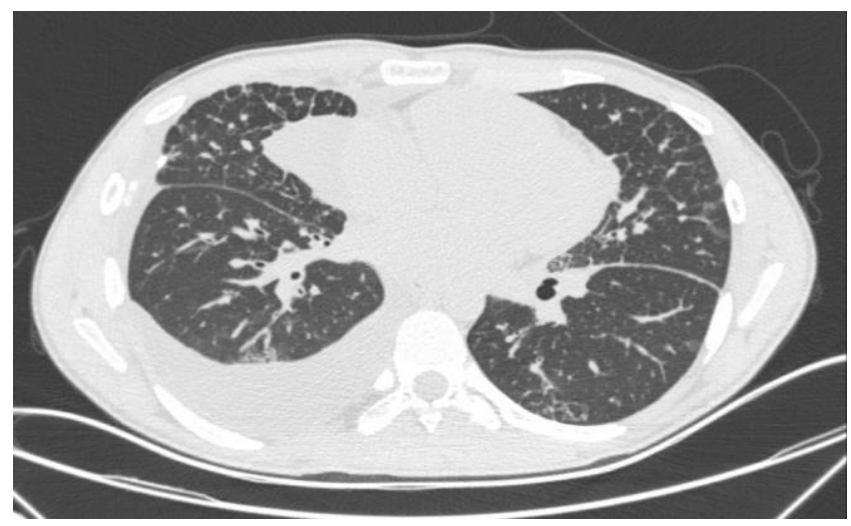

Figure 7: Thorax CT taken 18 months after the surgery; septal regular thickening in the middle lower lobe, as well as increased peribronchial nodular opacity in the subpleural area, pleural effusion extending into the fissure at a depth of $4 \mathrm{~cm}$ on the right lung

\section{DISCUSSION}

Lymphangiomas are anomalies caused by excessive proliferation of differentiated lymphoid tissue. According to their size, they are classified into capillary, cavernous and cystic lymphangiomas. Although vascular malformations are divided into two as vascular tumors (hemangioma) and vascular malformations according to Mullikan and Glowacki classification (1982); Landing and Faber also divided lymphangiomas into four; capillary, cavernous, cystic (hygroma) and hemangiolymphangioma (5-6).

Hemangiolymphangiomas are considered to be formed as a result of excessive proliferation of vascular formations during the angiogenesis process. They are named as hemangiolymphangioma since they contain lymphatic and capillary formations. Although they are classified as benign, invasion of the peripheral tissue by the cystic lesion can be witnessed when it is large in size. Although the pathophysiology has not been fully explained, mutations in FGF-4, PDGF-b, and tyrosine kinase genes are thought to be associated with familial type hemangiomas. Even though they are generally seen sporadically, infantile hemangiomas can be inherited as autosomal dominant. Most of them are seen in infancy, and the incidence in Caucasian race has been reported between 4-10\%. The most frequent regions where the lesions seen are; head and neck (59\%), trunk (24\%), lower extremities (10\%), upper extremities (7\%) having a large scale from hypopigmented macular lesion to dark macular lesion. The male: female ratio is given as 2.5: 1 (6-7).

The male patient in our case was diagnosed in adolescence, not in infancy and the diagnosis was made from the lung after wedge resection, not from the head and neck region as mostly reported. Clinical symptoms can range between a simple wheezing to advanced stage respiratory failure in adults. The diagnosis can be made even clinically in cases where the tumor is on the visible areas, but this was not possible in our case. In our opinion; the young age of our patient combined with absence of chronic illness and smoking history are also effective on his mild clinical state despite his illness. The only complaints he applied to hospital with were dyspnea and cough for two months; there were no signs of clubbing, cyanosis, etc. and his oxygen saturation was normal. The only feature on physical examination was the fine cracks heard in the basals. He didn't get diagnosed until present day since he didn't show any symptoms.

Pulmonary function tests (PFT) may show restrictive or mixed properties in general. In our case, the PFT had a restrictive pattern with a decreased FEVI and an increased FEV1 / FVC ratio.

Chest radiographs and CTs do not reveal pathological findings specifically to hemangiolymphangioma. Similar to our case, diffuse pleural effusion, diffuse interseptal 
and peribronchial thickening are generally reported in CTs. In cases where fiberoptic bronchoscopy was performed, the results revealed findings such as mucosal edema, bronchial narrowing, even thin vesicles filled with chylous fluid on the bronchial walls in case of advanced disease. In this case, diffuse interseptal and peribronchial thickening was notable on CT, and diffuse bronchiectasis honeycomb view was noted on chest radiography. It has been shown that open lung biopsy gives more accurate results in diagnosis, so the patient was evaluated in the surgical council (7-8).

Since $75 \%$ of asymptomatic hemangiomas regress on their own, follow-up without treatment is recommended. The recommended treatment options are generally palliative treatment. However, if severe deformity or lifethreatening dyspnea is seen, systemic glucocorticoid is recommended as the first-choice medical treatment (5). In addition; Interferon alpha is the preferred agent in the cases where beta-blocker and cortisol are ineffective. The latest publications recommend agents such as propranolol, sirolimus and bevacizumab for treatment. These agents have been shown to provide remission with less toxicity (3).

We followed our case under propranolol after surgery in line with the new recommendations. In case of pleural effusion control, therapeutic thoracentesis and pleurodesis are applied for palliative treatment. Therapeutic thoracentesis was not needed as no pleural effusion was observed in the patient's postoperative outpatient clinic controls. The postoperative chylothorax occured in our case shows similarity to lymphangiomatosis and should be kept in mind in differential diagnosis.

\section{CONCLUSION}

Although pulmonary hemangiolymphangiomas occur mostly in infancy and childhood, they may rarely be seen in adults. In differential diagnosis, lung involvement of lymphangioleimyomatosis, hemangioma, lymphangectasis, Kaposi's sarcoma should be considered. This rare disease should be considered in interstitial lung diseases along with prolonged chylothorax.

\section{CONFLICTS OF INTEREST}

None declared.

\section{AUTHOR CONTRIBUTIONS}

Concept - G.O., E.Y.D., S.O.M., N.F., E.C.S., E.Ç., M.M.; Planning and Design - G.O., E.Y.D., S.O.M., N.F., E.C.S., E.Ç., M.M.; Supervision - G.O., E.Y.D., S.O.M.,
N.F., E.C.S., E.Ç., M.M.; Funding - E.C.S., E.Ç., M.M.; Materials - S.O.M., E.Y.D., M.M.; Data Collection and/or Processing - G.O., E.Y.D., S.O.M., N.F., E.C.S., E.Ç., M.M.; Analysis and/or Interpretation - G.O., E.C.S., E.Ç., N.F.; Literature Review - G.O., E.C.S., E.Ç.; Writing - G.O., E.C.S., E.Ç.; Critical Review - G.O., C

\section{YAZAR KATKILARI}

Fikir - G.O., E.Y.D., S.O.M., N.F., E.C.S., E.Ç., M.M.; Tasarım ve Dizayn - G.O., E.Y.D., S.O.M., N.F., E.C.S., E.Ç., M.M.; Denetleme - G.O., E.Y.D., S.O.M., N.F., E.C.S., E.Ç., M.M.; Kaynaklar - E.C.S., E.Ç., M.M.; Malzemeler - S.O.M., E.Y.D., M.M.; Veri Toplama ve/veya İşleme - G.O., E.Y.D., S.O.M., N.F., E.C.S., E.Ç., M.M.; Analiz ve/veya Yorum - G.O., E.C.S., E.Ç., N.F.; Literatür Taraması - G.O., E.C.S., E.Ç.; Yazıyı Yazan - G.O., E.C.S., E.Ç.; Eleştirel İnceleme - G.O., E.C.S., E.Ç.

\section{REFERENCES}

1. Manickam S, Sasikumar P, Kishore BN, and Joy S. Hemangiolymphangioma of buccal mucosa: A rare case report. J Oral Maxillofac Pathol 2017; 21 (2): 282-285. [CrossRef]

2. Schwartz RA, Mancini M, Lin RL. Arterial Vascular Malformations Including Hemangiomas and Lymphangiomas Clinical Presentation. Medscape Education Global. Access date: 16 March 2021. Place of access: https://emedicine.medscape.com/article/1018071clinical.

3. Kadakia KC, Patel SM, Yi ES, Limper AH. Diffuse pulmonary lymphangiomatosis. Can Respir J 2013;20(1):5254. [CrossRef]

4. Martínez-Bucio V, De la Puente-Murgía R, GallardoMeza A, Zapata-Martínez SG, Zertuche-Coindreau JM, López-Valdés JC. Pulmonary haemangiolymphangioma as cause of hemodynamic decompensation, Revista Médica del Hospital General de México, Volume 79, Issue 4, 2016, Pages 210-215, ISSN 0185-1063. [CrossRef]

5. Mulliken JB, Glowacki J. Hemangiomas and vascular malformations in infants and children: a classification based on endothelial characteristics. Plast Reconstr Surg 1982;69:412-22. [CrossRef]

6. Faul JL, Berry GJ, Colby TV, Ruoss SJ, Walter MB, Rosen GD, Raffin TA. Thoracic Lymphangiomas, Lymphangiectasis, Lymphangiomatosis, and Lymphatic Dysplasia Syndrome. April 2000. American journal of respiratory and critical care medicine. 161. 1037-46. [CrossRef] 
7. Nakamura T, Tamanuki K, Ko, G, Oguri, M, Akita C, Kitaoka C, Nakamura T and Saikawa, Y. Chronic thromboembolic pulmonary hypertension related to hemangiolymphangioma. Case Reports in Clinical Medicine 2014;3:36-37. [CrossRef]
8. Murphy T, Ramai D, Lai J, Sullivan K, Grimes C. Adult neck hemangiolymphangioma: a case and review of its etiology, diagnosis and management, J Surg Case Rep 2017;31:2017(8):rix168. [CrossRef] 